\title{
Chromosome region maintenance 1 expression and its association with clinical pathological features in primary carcinoma of the liver
}

\author{
QIAO-LING XIE, YUE LIU and YING ZHU \\ Department of Infectious Diseases, The First Affiliated Hospital of Dalian Medical University, \\ Dalian, Liaoning 116000, P.R. China
}

Received July 27, 2015; Accepted February 19, 2016

DOI: $10.3892 / \mathrm{etm} .2016 .3283$

\begin{abstract}
Liver cancer is the third leading cause of cancer-associated mortality worldwide. Recurrence and metastasis are the major factors affecting the prognosis; thus, investigation of the underlying molecular mechanisms of invasion and metastasis, and detection of novel drug target may improve the mortality rate of liver cancer patients. Chromosome region maintenance 1 (CRM1) recognizes specific leucine-rich nuclear export signal sequences, and its overexpression is associated with tumor-suppressor gene inactivation, proliferation, invasion and resistance to chemotherapy. The aim of the present study was to examine the association of CRM1 expression with the clinical and pathological features of primary liver cancer. In total, 152 cases diagnosed with liver cancer were included. CRM1 expression was detected in cancer tissues and adjacent normal tissues by immunohistochemical assay. No statistically significant difference was found between the CRM1 expression levels in tumor and adjacent normal tissues $(\mathrm{P}=0.106)$. However, CRM1 expression in adjacent normal tissues was higher compared with that in tumor tissues in the negative hepatitis $\mathrm{B}$ envelope antigen $(\mathrm{HBeAg} ; \mathrm{P}=0.029)$ and low differentiation $(\mathrm{P}=0.004)$ groups. In tumor tissues, CRM1 expression was significantly correlated with differentiation $(\mathrm{P}=0.045)$, whereas in adjacent normal tissues, CRM1 expression was significantly correlated with the tumor diameter $(\mathrm{P}=0.004)$. Therefore, it can be concluded that CRM1 is highly expressed in both tumor and adjacent normal tissues. Furthermore, CRM1 expression is associated with the tumor differentiation degree and diameter. Lower differentiation and larger tumor diameter resulted in higher CRM1 expression in adjacent normal tissues, and higher tendency for invasion and metastasis. In addition, the risk of invasion and metastasis remains in chronic hepatitis $\mathrm{B}$ patients with negative $\mathrm{HBeAg}$.
\end{abstract}

Correspondence to: Ms. Ying Zhu, Department of Infectious Diseases, The First Affiliated Hospital of Dalian Medical University, 222 Zhongshan Road, Xigang, Dalian, Liaoning 116000, P.R. China E-mail: zhuyingsh52@126.com

Key words: chromosome region maintenance 1, hepatocellular carcinoma, immunohistochemical, hepatitis B virus, cirrhosis

\section{Introduction}

Liver cancer is the fifth most common type of cancer and the third leading cause of cancer-associated mortality in the worldwide population (1). The incidence and mortality rates of liver cancer are continuously increasing, with $\sim 700,000$ people diagnosed with liver cancer annually, among which hepatocellular carcinoma (HCC) constitutes $>80 \%$ of cases $(2,3)$. The hepatitis B virus (HBV) is a major risk factor for liver cancer (4). HBV is an oncogenic virus that can cause HCC through direct and indirect signaling pathways (5). Continuous hepatocyte injury and regeneration in liver disease result in increased liver cell turnover and accumulation of critical mutations in the host genome, which can in turn cause gene alterations, including the activation of oncogenes or inactivation of tumour suppressor genes (5). Since early diagnosis of liver cancer is challenging, the majority of HCC patients suffer from poor prognosis. Although great progress has been achieved in cancer treatment using methods such as surgery, liver transplantation, radiofrequency ablation and transcatheter arterial chemoembolization, the majority of HCC patients succumb due to invasion or distant metastasis to other organs $(6,7)$. Therefore, research has focused on examining the molecular mechanisms underlying invasion and metastasis, as well as investigating the significant molecular markers of HCC metastasis and identifying novel targets. One of the most effective strategies for the successful management of HCC is the prevention of metastasis of cancer cells in order to reduce the mortality rate and improve the prognosis of liver cancer (8).

The underlying mechanism of cancer invasion and metastasis is a complicated multistep process involving multiple genetic and molecular alterations (9). Chromosome region maintenance 1 (CRM1), also known as exportin 1, was initially identified in eukaryotic cells, while human CRM1 was first attained by cloning in 1997 by Kudo et al (10). It consists of 1,071 amino acids, which can maintain the structure and function of chromosomes in the process of mitosis (10). CRM1 is a major nuclear export protein in mammals, which facilitates the transport of RNAs, proteins or other macromolecules across the nuclear membrane to the cytoplasm (11-14). In addition, CRM1 recognizes the leucine-rich nuclear export signal (NES) sequence. Numerous cargo proteins that are rich in NES sequences, including 
tumor suppressor protein p53, p27, p21 and Forkhead box O, depend on CRM1 for nuclear export function (15-19).

The transportation of macromolecules across the nuclear membrane is critical for the proper functioning of living cells. Accumulating evidence has suggested that cancer cells are able to escape antineoplastic mechanisms and benefit from prosurvival signals through the dysregulation of this system (20). The protein CRM1 is the only member of the karyopherin- $\beta$ protein family that contributes to the nucleocytoplasmic trafficking, and is considered to be an anti-apoptotic oncogenic protein in transformed cells (21). In cancer cells, overexpression of CRM1 results in alterations in nucleocytoplasmic trafficking and deregulation of ribosomal biogenesis, as well as in aberrant cytoplasmic localization of tumor suppressor proteins, cell cycle regulators and pro-apoptotic proteins (20). A large number of studies (22-24) have shown that imbalance of cell proliferation and cell death due to disorder of the cell cycle is the major cause of malignancy. Therefore, abnormally high expression of CRM1 is correlated with poor patient prognosis in various malignancies. For instance, Giovanni et al (25) have reported that overexpression of CRM1 is associated with survival difference of various tumors, including pancreatic, lung, ovarian and cervical cancer, as well as in osteosarcoma and leukemia. Anguinomycin and goniothalamin were found to be inhibitors of CRM1 $(26,27)$, thus the development of CRM1-specific small molecules as novel anti-cancer agents is considered. Currently, therapeutic targeting of CRM1 has emerged as the original specific inhibitor of CRM1, followed by the development of several next-generation small molecules, such as KPT-330 which is a selective inhibitor of nuclear export (20,28-29).

Since the role of CRM1 in oncogenesis has been revealed by various studies and the anti-tumor mechanism of CRM1 inhibition is gradually elucidated (30-33), it is crucial to focus on the association of CRM1 expression with malignancy and clinical features. Therefore, the present study aimed to detect the CRM1 protein expression in primary liver carcinoma and adjacent cancer tissues in order to investigate its association with clinical and pathological features using an immunohistochemical assay. Furthermore, the study aimed to provide new experimental evidence for the molecular mechanism of tumor growth, invasion, metastasis and molecular therapy of primary liver carcinoma.

\section{Materials and methods}

Human tissue samples. A total of 152 tumor tissues and adjacent normal tissues (which were located $<2 \mathrm{~cm}$ from the cancer tissue and were used as the controls) were obtained between January 2009 and June 2014. The liver samples were provided by the First Affiliated Hospital of Dalian Medical University (Dalian, China). All liver samples were collected during surgery and preserved in 10\% formaldehyde solution at room temperature. Approximately $1 \times 1 \times 0.3 \mathrm{~cm}^{3}$ liver samples were obtained and fixed with $10 \%$ formalin for $24 \mathrm{~h}$. The tissue samples were subsequently dehydrated using a fully-automated tissue processor (Tissue-Tek ${ }^{\circledR}$ VIP $^{\circledR} 6$ ) and embedded in paraffin using a paraffin-embedding device (Leica EG1160). All enrolled patients were diagnosed with primary cancer of the liver by pathological examination, which was based on the World Health Organization classification of tumors of the digestive system (34). Communication was conducted with patients prior to surgery and all patients voluntarily participate in the present study, providing written informed consents. Information collected from the patient records included the gender, age, cirrhosis status, hepatitis B surface antigen (HBsAg), hepatitis B envelope antigen (HBeAg), $\alpha$-fetoprotein (AFP), carcinoembryonic antigen (CEA), differentiation degree (including high, middle or low differentiation) (35) and American Joint Committee on Cancer (AJCC) stage (36). HBsAg, HBeAg, CEA and AFP levels were measured using an ELISA kits (Roche Cobas e601 Analyzer; Roche Diagnostics GmbH, Mannheim, Germany). Detailed clinical and pathological features of these patients are shown in Table I.

The expression levels of CRM1 in the tumor and adjacent normal control tissues were then examined. Furthermore, the clinical and pathological features of 152 liver cancer patients and their association with CRM1 were also investigated. The present study was approved by the Ethics Committee of the The First Affiliated Hospital of Dalian Medical University.

Instruments and reagents. A Leica EG1160 paraffin-embedding device, a Leica RM2245 microtome, a drying device and a Leica DM2500 microscope were purchased from Leica Biosystems (Wetzlar, Germany). In addition, a Tissue-Tek VIP6 fully-automated tissue processor was purchased from Sakura Finetek (Tokyo, Japan). The primary antibody used in the present study was a rabbit anti-human CRM1 antibody (dilution, 1:100; ab191081; Abcam, Cambridge UK), and the secondary antibody was a horseradish peroxidase-conjugated goat anti-mouse/rabbit immunoglobulin G polymer (dilution, 1:1,000; Fuzhou Maixin Biological Technology Development Company, Fujian, China). Furthermore, phosphate-buffered saline (PBS), 3,3'-diaminobenzidine (DAB) chromogenic reagent and Tris-EDTA buffer $(\mathrm{pH} 9.0)$ were purchased from Zhongshan Jinqiao Biotechnology Co., Ltd. (Beijing, China). Other reagents, including xylene and ethanol (70, 90 and 100\%), were purchased from Shunda Chemicals Co. Ltd. (Xi'an, China).

Immunohistochemical analysis. The expression and intracellular localization of CRM1 in tumor and adjacent normal tissues were determined immunohistochemically. The tissue samples were dehydrated using the fully automated tissue processor (Tissue-Tek VIP6) and embedded in paraffin using a paraffin-embedding device (Leica EG1160). The tissue samples were then sectioned in $2-\mu \mathrm{m}$ specimens with a microtome (Leica RM2245) and dried at $60^{\circ} \mathrm{C}$ for $2 \mathrm{~h}$ using a drying device. Subsequent to deparaffinization in xylene for $10 \mathrm{~min}$ and rehydration in ascending grades of ethanol (70\% for $2 \mathrm{~min}, 95 \%$ for $2 \mathrm{~min}$ and $100 \%$ for $2 \mathrm{~min}$ ), high temperature antigen retrieval was conducted for 3 min using 0.01 M Tris-EDTA buffer ( $\mathrm{pH} 9.0)$ and a standard pressure-cooker. All sections were subjected to endogenous biotin blocking $\left(3 \% \mathrm{H}_{2} \mathrm{O}_{2}\right)$ and incubated for $10 \mathrm{~min}$ at room temperature. Tissues were washed with PBS and then incubated with the CRM1 primary antibody (ab191081) at $4^{\circ} \mathrm{C}$ overnight. Subsequently, the tissues were washed with PBS and incubated with secondary antibody for $1 \mathrm{~h}$ at room temperature. After tissues were washed with PBS, a DAB chromagen 
Table I. Clinical and pathological features of patients with primary cancer of the liver.

\begin{tabular}{|c|c|}
\hline Variable & Percentage $(\%)$ \\
\hline No. of patients & $152(100.0)$ \\
\hline \multicolumn{2}{|l|}{ Gender } \\
\hline Male & $122(80.3)$ \\
\hline Female & 30 (19.7) \\
\hline \multicolumn{2}{|l|}{ Age, years } \\
\hline$\leq 55$ & $77(50.7)$ \\
\hline$>55$ & $75(49.3)$ \\
\hline \multicolumn{2}{|l|}{ Diameter, cm } \\
\hline$\leq 5$ & $86(56.6)$ \\
\hline$>5$ & $66(43.4)$ \\
\hline \multicolumn{2}{|l|}{ No. of tumors } \\
\hline 1 & $136(89.5)$ \\
\hline$\geq 2$ & $16(10.5)$ \\
\hline \multicolumn{2}{|l|}{ Cirrhosis } \\
\hline+ & $102(67.1)$ \\
\hline- & $50(32.9)$ \\
\hline \multicolumn{2}{|l|}{ HBsAg } \\
\hline+ & $139(91.4)$ \\
\hline- & $13(8.6)$ \\
\hline \multicolumn{2}{|l|}{$\mathrm{HBeAg}$} \\
\hline+ & $31(20.4)$ \\
\hline- & $121(79.6)$ \\
\hline \multicolumn{2}{|l|}{$\mathrm{AFP}, \mu \mathrm{g} / 1$} \\
\hline$\leq 400$ & $120(79.0)$ \\
\hline$>400$ & $32(21)$ \\
\hline \multicolumn{2}{|l|}{$\mathrm{CEA}, \mu \mathrm{g} / 1$} \\
\hline$\leq 5$ & $116(76.3)$ \\
\hline$>5$ & $36(23.7)$ \\
\hline \multicolumn{2}{|c|}{ Differentiation degree } \\
\hline High & $32(21.0)$ \\
\hline Middle & $53(34.9)$ \\
\hline Low & $67(44.1)$ \\
\hline \multicolumn{2}{|l|}{ AJCC stage } \\
\hline I & $131(86.2)$ \\
\hline II & $9(5.9)$ \\
\hline III & $10(6.6)$ \\
\hline IV & $2(1.3)$ \\
\hline
\end{tabular}

CRM1, chromosome region maintenance 1 ; HBsAg, hepatitis B surface antigen; $\mathrm{HBeAg}$, hepatitis $\mathrm{B}$ envelope antigen; AFP, $\alpha$-fetoprotein; CEA, carcinoembryonic antigen; AJCC, American Joint Committee on Cancer; +, positive; -, negative.

substrate was used, and the tissues were washed in PBS and stained with hematoxylin (Shunda Chemical Co., Ltd., Xi'an, China). Following dehydration in ascending grades of alcohol, clearing in xylene, drying and sealing with resinene tablets (Ziyi Co., Shanghai, China), the tissue sections were examined under a Leica DM2500 microscope.
Two experienced pathologist independently observed the distribution characteristics of CRM1 expression using an optical microscope. Brown staining indicated positive staining for CRM1. Five high-power fields (magnification, x200) of each section were randomly selected and images were captured with the Leica DM2500 microscope. Next, the area of interest was selected and the value of optical density of each photo was detected by an image analysis software (Image-Pro Plus version 6.0; Media Cybernetics, Inc., Rockville, MD, USA). The mean value of the immunohistochemical optical density was determined as the final expression value of each tissue sample.

Statistical analysis. All statistical analyses were performed using SPSS version 19.0 (IBM Corp., Armonk, NY, USA). The results are expressed as the mean \pm standard deviation. Comparisons between the mean values were performed using Student's t test, analysis of variance and Fisher's least significant difference test. A P-value of $<0.05$ was considered as statistically significant.

\section{Results}

Immunohistochemical analysis results. Since all patients did not exhibit CRM1 expression in the adjacent normal tissue samples, only 101 cases with CRM1 expression in both the tumor tissue and adjacent normal tissue samples were further analyzed. The results indicated that CRM1 was highly expressed in both tumor and adjacent normal tissues, but the expression was not statistically significant between the two groups $(\mathrm{P}=0.106$; Table II). Subsequently, the association between CRM1 expression and individual clinical features of the patients was further investigated. CRM1 expression of adjacent normal tissues was found to be significantly higher compared with that of the tumor tissues in the low differentiation $(\mathrm{P}=0.004$; Fig. 1) and negative $\mathrm{HBeAg}(\mathrm{P}=0.035$; Fig. 2) specimens. However, as shown in Table II, the CRM1 expression of tumor tissues was not significantly lower compared with that in the adjacent normal tissues for other parameters (all $\mathrm{P}>0.05$ ), including gender (male, $\mathrm{P}=0.144$; female, $\mathrm{P}=0.508$ ), age (patients $\leq 55$ years, $\mathrm{P}=0.614$; patients $>55$ years, $\mathrm{P}=0.069$ ), cirrhosis status (positive, $\mathrm{P}=0.434$; negative, $\mathrm{P}=0.080$ ), positive HBsAg $(\mathrm{P}=0.091)$, negative HBsAg $(\mathrm{P}=0.691)$, positive HBeAg $(\mathrm{P}=0.474)$ AFP $(\leq 400 \mu \mathrm{g} / 1, \mathrm{P}=0.255 ;>400 \mu \mathrm{g} / \mathrm{l}$, $\mathrm{P}=0.133), \mathrm{CEA}(\leq 5 \mu \mathrm{g} / 1, \mathrm{P}=0.174 ;>5 \mu \mathrm{g} / 1, \mathrm{P}=0.843)$, tumor diameter $(\leq 5 \mathrm{~cm}, \mathrm{P}=0.097 ;>5 \mathrm{~cm}, \mathrm{P}=0.680)$ and AJCC stage I ( $\mathrm{P}=0.084$; Fig. 3). Since patients with AJCC stage II, III or IV were few in numbers, further analysis was not performed.

Analysis of CRM1 expression in tumor tissues. As shown in Fig. 4, positive CRM1 expression was found to be significantly correlated with low differentiation $(\mathrm{P}=0.045)$. However, negative associations were detected between positive CRM1 expression and other parameters, including gender $(\mathrm{P}=0.566)$, age $(\mathrm{P}=0.570)$, cirrhosis $(\mathrm{P}=0.457), \mathrm{HBs} \mathrm{Ag}(\mathrm{P}=0.412), \mathrm{HBeAg}$ $(\mathrm{P}=0.322)$, AFP $(\mathrm{P}=0.308), \mathrm{CEA}(\mathrm{P}=0.225)$, tumor diameter $(\mathrm{P}=0.428)$ and AJCC stage (all $\mathrm{P}>0.05$; Table III).

Analysis of CRM1 expression in adjacent normal tissue. As shown in Fig. 5, positive CRM1 expression was found to be significantly correlated with the tumor diameter in adjacent 
Table II. Association of CRM1 expression of tumor and adjacent normal tissues with clinical pathological features of patients.

\begin{tabular}{|c|c|c|c|c|c|}
\hline \multirow[b]{2}{*}{ Feature } & \multirow[b]{2}{*}{ No. } & \multicolumn{2}{|c|}{ CRM1 (IOD) } & \multirow[b]{2}{*}{ T-value } & \multirow[b]{2}{*}{ P-value } \\
\hline & & Tumor tissues & Adjacent normal tissues & & \\
\hline All patients & 101 & $134,737.84 \pm 144,343.88$ & $165,603.86 \pm 141,841.21$ & 1.632 & 0.106 \\
\hline \multicolumn{6}{|l|}{ Gender } \\
\hline Male & 83 & $142,175.00 \pm 199,338.96$ & $172,651.86 \pm 137,014.50$ & 1.477 & 0.144 \\
\hline Female & 18 & $100,444.32 \pm 116,058.22$ & $133,104.73 \pm 162,584.74$ & 0.676 & 0.508 \\
\hline \multicolumn{6}{|l|}{ Age, years } \\
\hline$\leq 55$ & 54 & $141,103.59 \pm 165,342.28$ & $154,336.02 \pm 128,576.80$ & 0.507 & 0.614 \\
\hline$>55$ & 47 & $127,424.01 \pm 117,018.72$ & $178,549.88 \pm 156,105.03$ & 1.861 & 0.069 \\
\hline \multicolumn{6}{|l|}{ Cirrhosis } \\
\hline+ & 65 & $149,593.95 \pm 128,705.42$ & $169,193.31 \pm 140,717.66$ & -0.787 & 0.434 \\
\hline- & 36 & $107,914.32 \pm 167,596.64$ & $159,122.90 \pm 145,626.71$ & -1.806 & 0.080 \\
\hline \multicolumn{6}{|l|}{ HBsAg } \\
\hline+ & 94 & $132,439.61 \pm 146,800.11$ & $166,820.07 \pm 144,761.11$ & -1.710 & 0.091 \\
\hline- & 7 & $165,599.83 \pm 109,678.66$ & $149,271.89 \pm 100,829.23$ & 0.418 & 0.691 \\
\hline \multicolumn{6}{|l|}{$\mathrm{HBeAg}$} \\
\hline+ & 82 & $138,606.82 \pm 155,005.00$ & $153,497.11 \pm 131,531.72$ & -0.719 & 0.474 \\
\hline- & 19 & $118,040.13 \pm 85,257.80$ & $217,854.03 \pm 174,268.98$ & -2.285 & 0.035 \\
\hline \multicolumn{6}{|l|}{$\mathrm{AFP}, \mu \mathrm{g} / 1$} \\
\hline$\leq 400$ & 86 & $136,995.87 \pm 149,979.55$ & $160,477.47 \pm 140,133.43$ & -1.146 & 0.255 \\
\hline$>400$ & 15 & $121,691.05 \pm 113,876.58$ & $204,903.30 \pm 153,643.40$ & -1.603 & 0.133 \\
\hline \multicolumn{6}{|l|}{$\mathrm{CEA}, \mu \mathrm{g} / 1$} \\
\hline$\leq 5$ & 81 & $130,923.14 \pm 148,572.40$ & $153,332.91 \pm 136,638.43$ & 1.732 & 0.174 \\
\hline$>5$ & 20 & $192,052.42 \pm 145,804.10$ & $201,119.63 \pm 175,908.90$ & -0.214 & 0.843 \\
\hline \multicolumn{6}{|c|}{ Diameter, cm } \\
\hline$\leq 5$ & 65 & $131,421.49 \pm 153,865.43$ & $172,529.67 \pm 154,822.13$ & -1.683 & 0.097 \\
\hline$>5$ & 36 & $140,725.71 \pm 127,204.82$ & $153,098.93 \pm 115,767.30$ & -0.416 & 0.680 \\
\hline \multicolumn{6}{|c|}{ Differentiation } \\
\hline Low & 44 & $168,498.02 \pm 137,486.15$ & $952,982.20 \pm 103,493.34$ & 3.017 & 0.004 \\
\hline Middle & 35 & $153,890.49 \pm 139,782.16$ & $164,034.91 \pm 135,824.15$ & -0.294 & 0.770 \\
\hline High & 22 & $172,440.15 \pm 201,919.78$ & $178,450.43 \pm 158,258.18$ & 0.141 & 0.889 \\
\hline \multicolumn{6}{|l|}{ AJCC stage } \\
\hline $\mathrm{I}$ & 91 & $133,074.18 \pm 141,755.58$ & $167,146.51 \pm 144,340.17$ & -1.750 & 0.084 \\
\hline
\end{tabular}

CRM1, chromosome region maintenance 1; IOD, immunohistochemical optical density; HBsAg, hepatitis B surface antigen; HBeAg, hepatitis B envelope antigen; AFP, $\alpha$-fetoprotein; AJCC, American Joint Committee on Cancer; +, positive; -, negative.

normal tissues $(\mathrm{P}=0.004)$. However, negative associations were detected between positive CRM1 expression and other parameters, including gender $(\mathrm{P}=0.383)$, age $(\mathrm{P}=0.144)$, cirrhosis $(\mathrm{P}=0.394)$, HBsAg $(\mathrm{P}=0.257)$, HBeAg $(\mathrm{P}=0.125)$, AFP $(\mathrm{P}=0.718)$, CEA $(\mathrm{P}=0.355)$, differentiation degree and AJCC stage (all P>0.05; Table IV).

\section{Discussion}

Epidemiological investigations have shown that primary liver cancer is connected with polygenic susceptibility (37). The development of cancer is a complicated process that includes cell proliferation, inactivation of tumor-suppressor gene and activation of oncogene mediated by numerous signaling cascades $(9,37)$. CRM1, a member of the karyopherin- $\beta$ protein family, is a nuclear export receptor that, upon binding with RanGTP, is able to recognize the substrates rich in NES $(21,38)$. The CRM1 signaling cascade is important in mediating the expression of growth factors and cytokines, serving a critical role in the malignant transformation of cells (30-33,38-41). To date, studies have demonstrated that CRM1 is strongly expressed in various types of tumor cells, and it may promote malignant transformation of mammal cells. In addition, its overexpression is associated with cell carcinogenesis and poor prognosis of solid tumor (42-45). In human glioma cells overexpressing CRM1, tumor cell growth was promoted by the nuclear export of p27 protein (42). In lung cancer, CRM1 was found to increase 
A

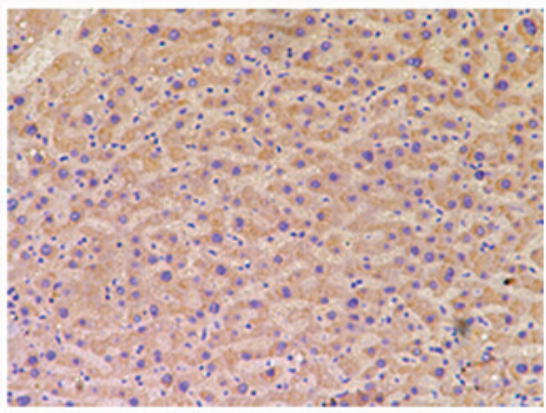

B

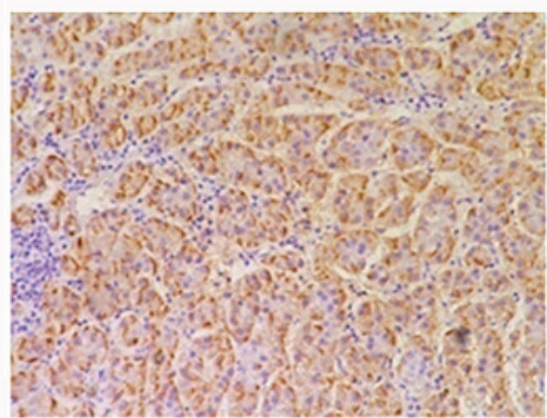

C

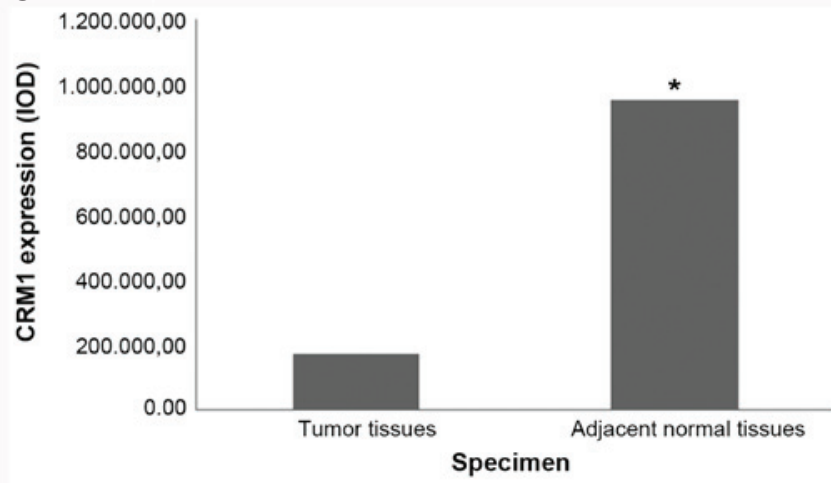

Figure 1. Immunohistochemical analysis of CRM1 expression in (A) adjacent normal control and (B) tumor tissues, in the low differentiation group. (C) CRM1 expression was higher in the adjacent normal tissues compared with the tumor tissues (low differentiation group). CRM1, chromosome region maintenance 1 ; IOD, immunohistochemical optical density. ${ }^{*} \mathrm{P}<0.05$, vs. tumor tissues.

tumor growth by changing the suppressor gene p53 subcellular localization (43).

In the present study, due to limited availability of normal human liver tissues, tumor tissues were collected and their adjacent normal tissues were used as the control group. The current study detected the CRM1 expression in tumor tissues and adjacent normal tissues, and estimated the association of CRM1 expression with various clinical and pathological features, including the patient gender, age, cirrhosis statis, $\mathrm{HBsAg}, \mathrm{HBeAg}$, tumor diameter, AFP, differentiation degree and AJCC stage. The results aimed to provide further evidence on whether CRM1 serves an important role in liver cancer invasion and metastasis, and whether it is an important molecular mechanism underlying the progression of liver cancer.

The results of the present study demonstrated that although male patients $>55$ years of age had higher expression levels of CRM1 in adjacent normal tissues compared with tumor tissues, no significant difference was observed. The number of male patients with liver cancer were higher than female patients, and
A

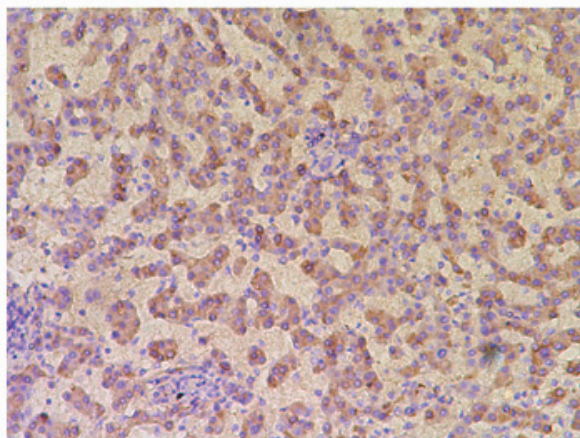

B

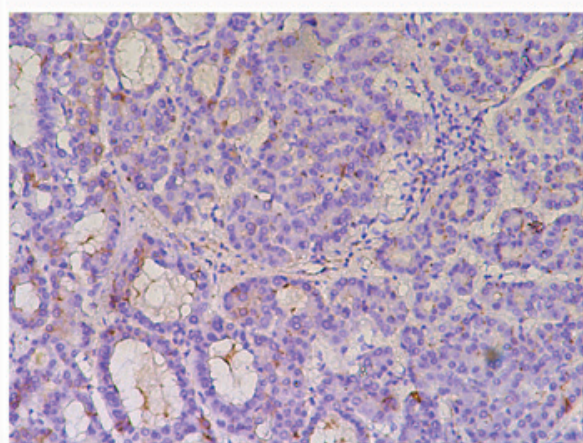

C

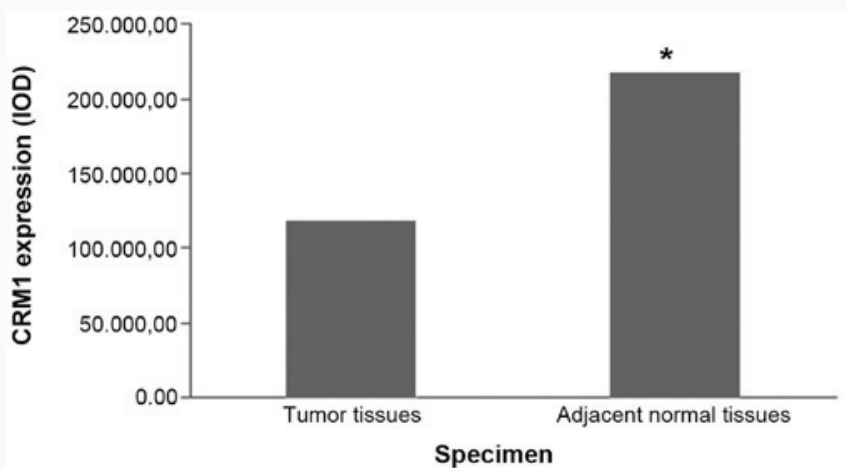

Figure 2. Immunohistochemical analysis of CRM1 expression in (A) adjacent normal control and (B) tumor tissues, in the negative $\mathrm{HBeAg}$ group. (C) CRM1 expression in adjacent normal tissues is higher compared with that in tumor tissues, in the negative HBeAg specimens. CRM1, chromosome region maintenance 1 ; $\mathrm{HBeAg}$, hepatitis $\mathrm{B}$ envelope antigen; IOD, immunohistochemical optical density. ${ }^{*} \mathrm{P}<0.05$, vs. tumor tissues.

El-Serag et al (2) also reported that the ratio of affected men to affected women was between 2:1 and 4:1. Men are therefore more likely to develop liver cancer than women, but whether liver cancer metastasis affects a gender or age more than the other requires further study. The results of the present study revealed that CRM1 was expressed similarly in tumor and adjacent normal tissues. However, a higher CRM1 expression in adjacent normal tissues compared with that in tumor tissues was found to be significantly correlated with the differentiation degree. In addition, in the tumor tissue group, positive CRM1 expression was significantly correlated with the differentiation degree, whereas in the adjacent normal tissue group, positive CRM1 expression was observed to be significantly correlated with the tumor diameter. A low degree of differentiation and higher tumor diameter resulted in increased CRM1 expression in adjacent normal tissues; thus, CRM1 may participate in tumor cell metastasis and invasion to adjacent normal tissues. Numerous studies have confirmed an increased expression of 
Table III. Association between CRM1 expression of tumor tissues and clinical pathological features.

\begin{tabular}{|c|c|c|c|c|}
\hline Feature & No. & $\begin{array}{l}\text { CRM1 expression (IOD) } \\
\text { in tumor tissues }\end{array}$ & T-value & P-value \\
\hline \multicolumn{5}{|l|}{ Gender } \\
\hline Male & 120 & $143,353.57 \pm 151,369.26$ & 0.114 & 0.566 \\
\hline Female & 30 & $139,825.88 \pm 156,349.77$ & & \\
\hline \multicolumn{5}{|l|}{ Age, years } \\
\hline$\leq 55$ & 77 & $129,275.10 \pm 150,039.60$ & -1.102 & 0.570 \\
\hline$>55$ & 75 & $156,396.40 \pm 153,464.20$ & & \\
\hline \multicolumn{5}{|l|}{ Cirrhosis } \\
\hline+ & 102 & $157,349.60 \pm 147,664.49$ & 1.715 & 0.457 \\
\hline- & 50 & $112,685.13 \pm 157,300.15$ & & \\
\hline \multicolumn{5}{|l|}{$\mathrm{HBsAg}$} \\
\hline+ & 139 & $141,232.62 \pm 155,627.62$ & -0.377 & 0.412 \\
\hline- & 13 & $157,890.67 \pm 106,454.30$ & & \\
\hline \multicolumn{5}{|l|}{ HBeAg } \\
\hline+ & 120 & $142,652.84 \pm 157,021.42$ & 0.021 & 0.322 \\
\hline- & 31 & $143,295.45 \pm 135,059.08$ & & \\
\hline \multicolumn{5}{|l|}{$\mathrm{AFP}, \mu \mathrm{g} / \mathrm{l}$} \\
\hline$\leq 400$ & 120 & $135,903.39 \pm 147,779.25$ & -0.996 & 0.308 \\
\hline$>400$ & 30 & $166,934.08 \pm 171,099.53$ & & \\
\hline \multicolumn{5}{|l|}{$\mathrm{CEA}, \mu \mathrm{g} / 1$} \\
\hline$\leq 5$ & 116 & $135,737.99 \pm 150,342.95$ & -1.244 & 0.225 \\
\hline$>5$ & 36 & $183,316.95 \pm 158,906.97$ & & \\
\hline \multicolumn{5}{|l|}{ Diameter, cm } \\
\hline$\leq 5$ & 86 & $140,864.01 \pm 164,325.30$ & -0.166 & 0.428 \\
\hline$>5$ & 66 & $144,994.05 \pm 135,065.09$ & & \\
\hline Differentiation & & & & $0.045^{\mathrm{a}}, 0.155^{\mathrm{b}}, 0.771^{\mathrm{c}}$ \\
\hline Low & 67 & $169,434.42 \pm 154,982.45$ & & \\
\hline Moderate & 53 & $113,388.64 \pm 132,470.57$ & & \\
\hline High & 32 & $159,589.03 \pm 136,877.62$ & & \\
\hline AJCC & & & & $0.997^{\mathrm{d}}, 0.649^{\mathrm{e}}, 0.805^{\mathrm{f}}$, \\
\hline stage & & & & $0.747^{\mathrm{g}}, 0.821^{\mathrm{h}}, 0.674^{\mathrm{i}}$ \\
\hline I & 131 & $141,491.21 \pm 147,973.91$ & & \\
\hline II & 9 & $141,687.09 \pm 166,898.77$ & & \\
\hline III & 10 & $164,408.01 \pm 208,434.76$ & & \\
\hline IV & 2 & $114,490.13 \pm 121,496.74$ & & \\
\hline
\end{tabular}

Differentiation P-values: ${ }^{a}$ Low vs. moderate; blow vs. high; ' moderate vs. high. AJCC stage P-values: ${ }^{\mathrm{d} I}$ vs. II; ${ }^{\mathrm{e}} \mathrm{I}$ vs. III; ${ }^{\mathrm{f} I}$ vs. IV; ${ }^{\mathrm{g} I I}$ vs. III;

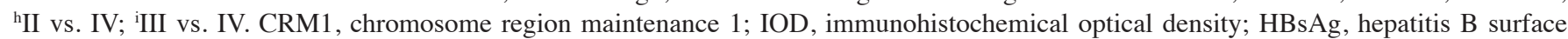
antigen; HBeAg, hepatitis B envelope antigen; AFP, $\alpha$-fetoprotein; AJCC, American Joint Committee on Cancer; +, positive; -, negative.

CRM1 in various solid tumors (such as glioblastoma, pancreatic cancer, ovarian cancer and cervical cancer) and hematologic malignancies $(33,44)$. Furthermore, previous studies revealed that the nuclear export of 221 types of NES-containing proteins was mediated by CRM1. Moreover, numerous NES-containing proteins are critical signaling molecules of tumor cell proliferation and malignant transformation (21-52). It is also estimated that CRM1 inhibitors may effectively inhibit the proliferation of tumor cells and accelerate apoptosis, while their efficacy may be enhanced when combined with chemotherapy drugs (21).
In fact, $\mathrm{HBV}$ is a major cause of primary cancer of liver (4). A study by Forgues et al (52) has investigated the interaction of the HBV X protein with the CRM1-dependent nuclear export pathway and suggested that CRM1 may serve a role in HBV X protein-mediated liver carcinogenesis. The oncogenic HBV X protein contains a functional NES motif and mutations of this motif result in nuclear redistribution of HBV X protein. In the present study, the association between $\mathrm{HBsAg} / \mathrm{HBeAg}$ and CRM1 expression in tumor tissues and adjacent normal tissues was investigated. The results showed 
Table IV. Association between CRM1 expression of adjacent normal tissues and clinical pathological features.

\begin{tabular}{|c|c|c|c|c|}
\hline Feature & Patients & CRM1 (IOD) & T-value & P-value \\
\hline \multicolumn{5}{|l|}{ Gender } \\
\hline Male & 83 & $172,651.86 \pm 137,014.50$ & 1.073 & 0.383 \\
\hline Female & 18 & $133,104.73 \pm 162,584.74$ & & \\
\hline \multicolumn{5}{|l|}{ Age, years } \\
\hline$\leq 55$ & 54 & $154,336.02 \pm 128,576.80$ & -0.855 & 0.144 \\
\hline$>55$ & 47 & $178,549.88 \pm 156,105.03$ & & \\
\hline \multicolumn{5}{|l|}{ Cirrhosis } \\
\hline+ & 65 & $169,193.31 \pm 140,717.66$ & 0.340 & 0.394 \\
\hline- & 36 & $159,122.89 \pm 145,626.71$ & & \\
\hline \multicolumn{5}{|l|}{$\mathrm{HBsAg}$} \\
\hline+ & 94 & $166,820.07 \pm 144,761.11$ & 0.314 & 0.257 \\
\hline- & 7 & $149,271.89 \pm 100,829.23$ & & \\
\hline \multicolumn{5}{|l|}{$\mathrm{HBeAg}$} \\
\hline+ & 19 & $217,854.03 \pm 174,268.98$ & 1.802 & 0.125 \\
\hline- & 82 & $153,497.11 \pm 131,531.72$ & & \\
\hline \multicolumn{5}{|l|}{$\mathrm{AFP}, \mu \mathrm{g} / 1$} \\
\hline$\leq 400$ & 86 & $160,477.47 \pm 140,133.43$ & -1.086 & 0.718 \\
\hline$>400$ & 14 & $204,903.30 \pm 153,643.40$ & & \\
\hline \multicolumn{5}{|l|}{$\mathrm{CEA}, \mu \mathrm{g} / 1$} \\
\hline$\leq 5$ & 81 & $153,332.91 \pm 136,638.43$ & -0.947 & 0.355 \\
\hline$>5$ & 20 & $192,052.42 \pm 145,804.10$ & & \\
\hline \multicolumn{5}{|l|}{ Diameter, cm } \\
\hline$\leq 5$ & 65 & $153,098.93 \pm 115,767.30$ & 0.658 & 0.004 \\
\hline$>5$ & 36 & $172,529.66 \pm 154,822.13$ & & \\
\hline Differentiation & & & & $0.653^{\mathrm{a}}, 0.790^{\mathrm{b}}, 0.529^{\mathrm{c}}$ \\
\hline Low & 44 & $168,498.02 \pm 137,486.15$ & & \\
\hline Moderate & 35 & $153,890.49 \pm 139,782.16$ & & \\
\hline High & 22 & $178,450.43 \pm 158,258.18$ & & \\
\hline AJCC stage & & & & $0.850^{\mathrm{d}}, 0.690^{\mathrm{e}}, 0.665^{\mathrm{f}}$ \\
\hline I & 91 & $167,146.51 \pm 144,340.17$ & & \\
\hline II & 5 & $179,673.43 \pm 153,475.79$ & & \\
\hline III & 4 & $137,812.58 \pm 97,291.86$ & & \\
\hline
\end{tabular}

Differentiation P-values: ${ }^{a}$ Low vs. moderate; ${ }^{b}$ low vs. high; ${ }^{c}$ moderate vs. high. AJCC stage P-values: ${ }^{\mathrm{d} I}$ vs. II; ${ }^{\mathrm{e} I}$ vs. III; fII vs. III. CRM1, chromosome region maintenance 1; HBsAg, hepatitis B surface antigen; HBeAg, hepatitis B envelope antigen; AFP, $\alpha$-fetoprotein; AJCC, American Joint Committee on Cancer; +, positive; -, negative.

that the CRM1 expression in adjacent normal tissues with positive HBsAg was higher compared with that in the tumor tissue group, but with no statistically significant difference observed. However, CRM1 expression in adjacent normal tissues was significantly higher compared with that in tumor tissues with a negative HBeAg status. According to these findings, it is suggested that liver cancer in patients with HBV infection, particularly patients with negative $\mathrm{HBeAg}$, is more likely to present invasion and metastasis. $\mathrm{E}$ antigen is encoded by the pre- $\mathrm{C}$ gene, and a longer duration of hepatitis $\mathrm{B}$ accompanied by a mutation to the pre-C gene will result in the absence of $\mathrm{E}$ antigen in the serum. However, the HBV DNA load will remain high, so HBeAg-negative patients may experience more severe liver inflammation and are more likely to develop liver cirrhosis and liver cancer as compared with $\mathrm{HBeAg}$-positive patients (53).

$\mathrm{HBV}$-associated or hepatitis $\mathrm{C}$ virus-associated liver fibrosis and cirrhosis are considered to be risk factors for the development of primary liver cancer $(54,55)$. The majority of primary liver cancer cases (even up $80 \%$ of cases) occurred in patients with HBV infection or cirrhosis in China (56). Cirrhosis has a significantly effect on the liver microenvironment, including increased extracellular matrix proteins and cytokines, angiogenesis and changes in the immune regulation mechanism. Changes in the liver microenvironment also affect the environment of tumor cells. In the present study, a negative association was detected between positive CRM1 expression and cirrhosis in the tumor tissues and adjacent normal tissues; however, CRM1 expression 


\section{A}
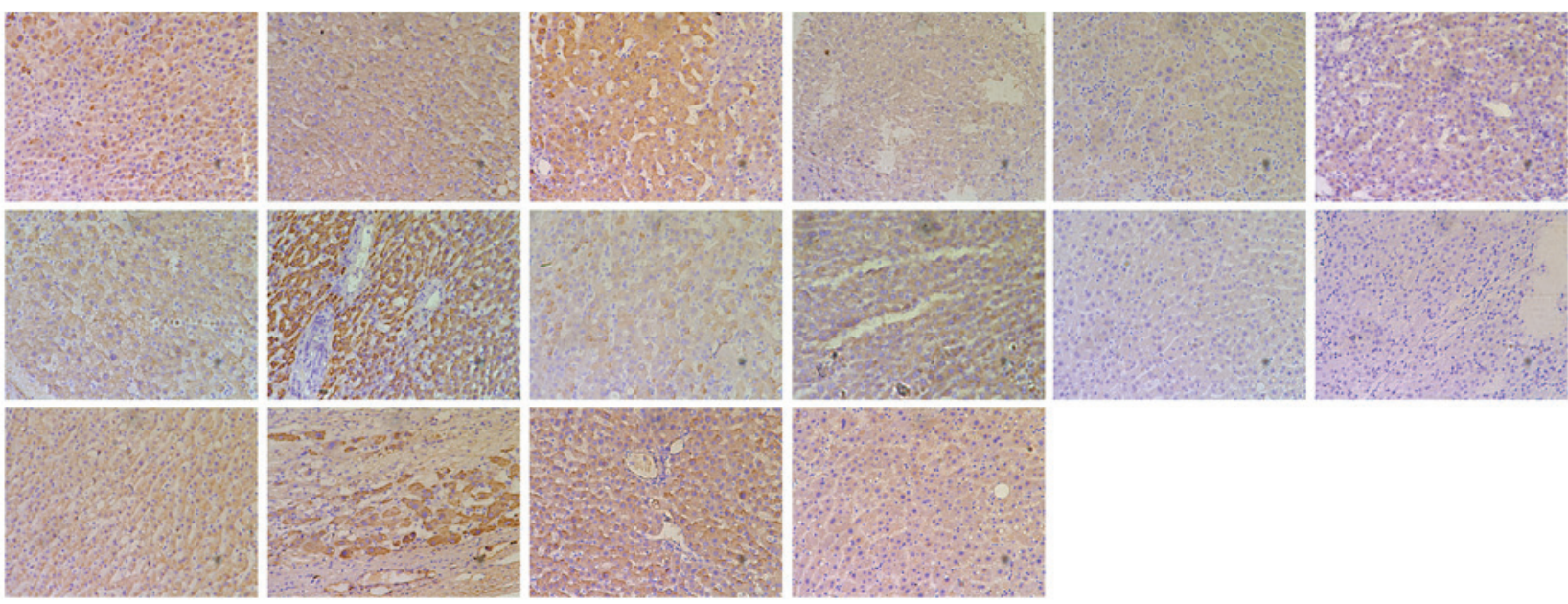

B
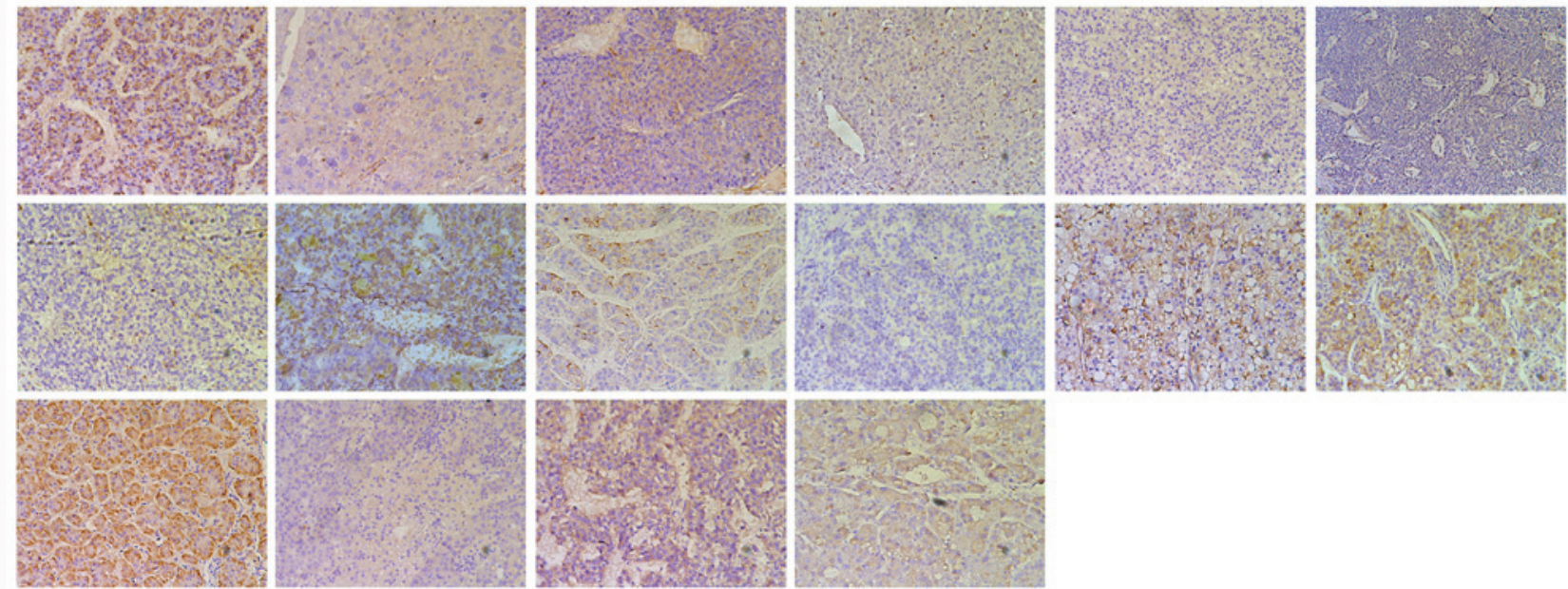

Figure 3. Immunohistochemical analysis of CRM1 expression in (A) adjacent normal control and (B) tumor tissues, including the following groups from the first column of the first row to the fourth column of the third row: Male, female, age $>55$ years, age $\leq 55$ years, cirrhosis, absence of cirrhosis, positive $\mathrm{HBs} A g$, negative HBsAg, positive HBeAg, AFP $>400 \mu \mathrm{g} / 1, \mathrm{AFP} \leq 400 \mu \mathrm{g} / \mathrm{l}, \mathrm{CEA}>5 \mu \mathrm{g} / 1$, CEA $\leq 5 \mu \mathrm{g} / 1$, tumor diameter $>5 \mathrm{~cm}$, tumor diameter $\leq 5 \mathrm{~cm}$ and AJCC stage I. CRM1, chromosome region maintenance 1; HBeAg, hepatitis B envelope antigen; AFP, $\alpha$-fetoprotein; CEA, carcinoembryonic antigen.

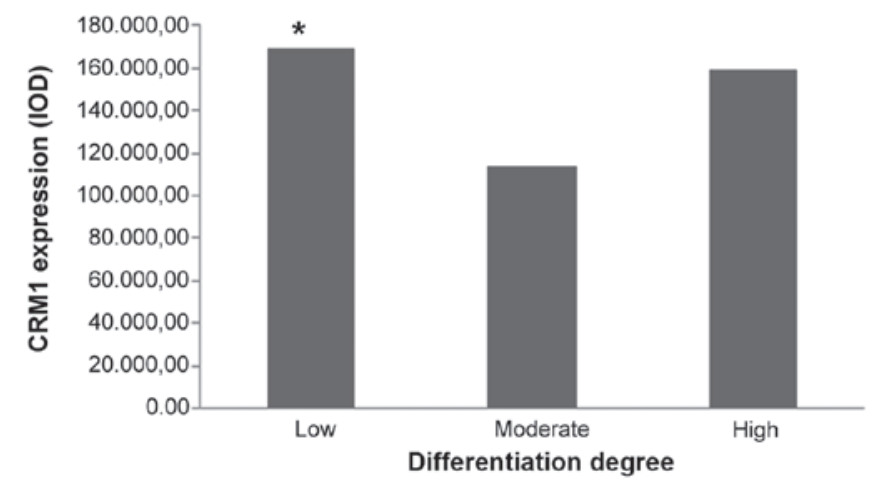

Figure 4. Association between CRM1 expression of tumor tissues and differentiation degree. CRM1, chromosome region maintenance 1 ; IOD, immunohistochemical optical density. ${ }^{*} \mathrm{P}<0.05$, vs. moderate.

in patients with cirrhosis was higher compared with that in non-cirrhotic patients in both tissue groups. This increased trend may suggest that cirrhosis is a dependent risk factor of invasion and metastasis of liver cancer. The study by Pascale et al (57) revealed that the CRM1 expression in liver fibrosis, cirrhosis and liver cancer increased by 2-2.9 times when compared with

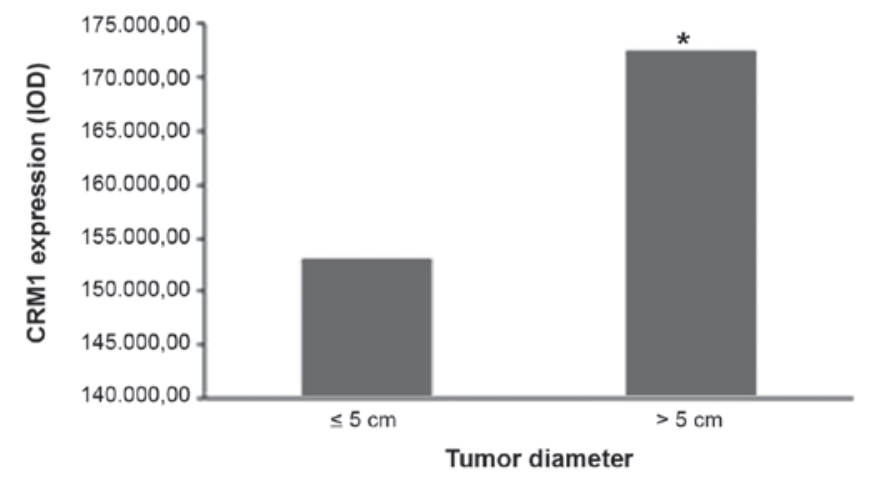

Figure 5. Association between CRM1 expression of adjacent normal tissues and diameter. CRM1, chromosome region maintenance 1 ; IOD, immunohistochemical optical density. ${ }^{*} \mathrm{P}<0.05$, vs. $\leq 5 \mathrm{~cm}$.

the expression in normal livers of mice (57). Therefore, overexpression of CRM1 may be an important molecular mechanism of cirrhosis evolution in liver cancer.

AFP and CEA are important serum markers of cancer diagnosis, and are usually applied in combination (58). In the present study, patients with high serum levels of AFP 
and CEA exhibited higher CRM1 expression both in tumor tissues and adjacent normal tissues compared with those with low levels of AFP and CEA. However, significant differences were not observed. These results suggested that high levels of AFP and CEA may be associated with the degree of malignancy of the liver cancer and how prone it is to metastasis. Ma et al (58) also reported that AFP levels were predictive of the malignant features and prognosis of liver cancer. However, the current study presented certain limitations. Although the sample size of the study is not particularly small, due to limited availability of fresh liver samples, only immunohistochemical assay was used to assess the CRM1 expression. Studies with much larger sample sizes and novel experimental methods are required to further investigate the molecular mechanism of tumor invasion and metastasis.

In conclusion, CRM1 is suggested to serve an important role in the invasion and metastasis of primary liver cancer. CRM1 expression was found to be associated with the differentiation degree and diameter of the tumor. A lower differentiation degree and larger tumor diameter resulted in higher CRM1 expression in adjacent normal tissues and increased the possibility of invasion and metastasis. Furthermore, chronic hepatitis $\mathrm{B}$ patients with negative $\mathrm{HBeAg}$ were at a high risk of invasion and metastasis. Therefore, a high expression of CRM1 may be an important molecular mechanism of cirrhosis evolution in liver cancer.

\section{Acknowledgements}

The authors would like to thank their colleagues at the Department of Pathology of The First Affiliated Hospital of Dalian Medical University for the help and technical guidance provided. This study was supported by The National Science Foundation of China (grant no. 81273925).

\section{References}

1. Jemal A, Bray F, Center MM, Ferlay J, Ward E and Forman D: Global cancer statistics. CA Cancer J Clin 61: 69-90, 2011.

2. El-Serag HB: Hepatocellular carcinoma. N Engl J Med 365: 1118-1127, 2011.

3. Forner A, Llovet JM and Bruix J: Hepatocellular carcinoma. Lancet 379: 1245-1255, 2012.

4. Di Bisceglie AM, Rustgi VK, Hoofnagle JH, Dusheiko GM and Lotze MT: NIH conference. Hepatocellular carcinoma. Ann Intern Med 108: 390-401, 1998.

5. But DY,Lai CL and Yuen MF: Natural history of hepatitis-related hepatocellular carcinoma. World J Gastroenterol 14: 1652-1656, 2008.

6. Dubbelboer IR, Lilienberg E, Ahnfelt E, Sjögren E, Axén N and Lennernäs $\mathrm{H}$ : Treatment of intermediate stage hepatocellular carcinoma: A review of intrahepatic doxorubicin drug-delivery systems. Ther Deliv 5: 447-466, 2014.

7. Villanueva A, Minguez B, Forner A, Reig M and Liovet JM: Hepatocellular carcinoma: Novel molecular approaches for diagnosis, prognosis, and therapy. Annu Rev Med 61: 317-328, 2010.

8. Li WX, Chen LP, Sun MY, Li JT, Liu HZ and Zhu W: 3'3-Diindolylmethane inhibits migration, invasion and metastasis of hepatocellular carcinoma by suppressing FAK signaling. Oncotarget 6: 23776-23792, 2015.

9. Villanueva A, Newell P, Chiang DY, Friedman SL and Llovet JM. Genomics and signaling pathways in hepatocellular carcinoma Semin Liver Dis 27: 55-76, 2007.

10. Kudo N, Khochbin S, Nishi K, Kitano K, Yanagida M, Yoshida M and Horinouchi S: Molecular cloning and cell cycle-dependent expression of mammalian CRM1, a protein involved in nuclear export of proteins. J Biol Chem 272: 29742-29751, 1997.
11. Nguyen KT, Holloway MP and Altura RA: The XPO1 nuclear export protein in normal development and disease. Int J Biochem Mol Biol 3: 137-151, 2012.

12. Turner JG, Dawson J and Sullivan DM: Nuclear export of proteins and drug resistance in cancer. Biochem Pharmacol 83: 1021-1032, 2012.

13. Muqbil I, Bao B, Abou-Samra AB, Mohammad RM and Azmi AS: Nuclear export mediated regulation of MicroRNAs: Potential target for drug intervention. Curr Drug Targets 14: 1094-1100, 2013.

14. Siddiqui $N$ and Borden KL: mRNA export and cancer. Wiley Interdiscip Rev RNA 3: 13-25, 2012.

15. Santiago A, Li D, Zhao LY, Godsey A and Liao D: p53 SUMOylation promotes its nuclear export by facilitating its release from the nuclear export receptor CRM1. Mol Biol Cell 24: 2739-2752, 2013.

16. Brodie KM and Henderson BR: Characterization of BRCA1 protein targeting, dynamics, and function at the centrosome: A role for the nuclear export signal, CRM1, and Aurora A kinase. J Biol Chem 287: 7701-7716, 2012.

17. Chan KS, Wong CH, Huang YF and Li HY: Survivin withdrawal by nuclear export failure as a physiological switch to commit cells to apoptosis. Cell Death Dis 1: e57, 2010.

18. Mariano AR, Colombo E, Luzi L, Martinelli P, Volorio S, Bernard L, Meani N, Bergomas R, Alcalay M and Pelicci PG: Cytoplasmic localization of NPM in myeloid leukemias is dictated by gain-of-function mutations that create a functional nuclear export signal. Oncogene 25: 4376-4380, 2006.

19. Henderson BR: Nuclear-cytoplasmic shuttling of APC regulates beta-catenin subcellular localization and turnover. Nat Cell Biol 2: 653-660, 2000.

20. Ishizawa J, Kojima K, Hail N Jr, Tabe Y and Andreeff M: Expression, function, and targeting of the nuclear exporter chromosome region maintenance 1 (CRM1) protein. Pharmacol Ther 153: 25-35, 2015

21. Xu D, Grishin NV and Chook YM: NESdb: A database of NES-containing CRM1 cargoes. Mol Biol Cell 23: 3673-3676, 2012.

22. Fabregat I: Dysregulation of apoptosis in hepatocellular carcinoma cells. World J Gastroenterol 15: 513-520, 2009.

23. Chiorazzi N: Cell proliferation and death: Forgotten features of chronic lymphocytic leukemia B cells. Best Pract Res Clin Haematol 20: 399-413, 2007.

24. Fulda S and Debatin KM: Apoptosis pathways in neuroblastoma therapy. Cancer Lett 197: 131-135, 2003.

25. Giovanni GL, Senapedis W, McCauley D, Baloglu E, Shacham S and Festuccia C: Nucleo-cytoplasmic tansport as a therapeutic target of cancer. J Hematol Oncol 7: 85, 2014.

26. Hamamoto $\mathrm{T}$, Uozumi $\mathrm{T}$ and Beppu T: Leptomycins A and B, new antifungal antibiotics. III. Mode of action of leptomycin B on Schizosaccharomyces pombe. J Antibiot (Tokyo) 38: 1573-1580, 1985.

27. Meissner T, Krause E and Vinkemeier U: Ratjadone and leptomycin B block CRM1-dependent nuclear export by identical mechanisms. FEBS Lett 576: 27-30, 2004.

28. Mutka SC, Yang WQ, Dong SD, Ward SL, Craig DA, Timmermans PB and Murli S: Identification of nuclear export inhibitors with potent anticancer activity in vivo. Cancer Res 69: 510-517, 2009.

29. Etchin J, Sanda T, Mansour MR, Kentsis A, Montero J, Le BT, Christie AL, McCauley D, Rodig SJ, Kauffman M, et al: KPT-330 inhibitor of CRM1 (XPO1)-mediated nuclear export has selective anti-leukaemic activity in preclinical models of T-cell acute lymphoblastic leukaemia and acute myeloid leukaemia. $\mathrm{Br}$ J Haematol 161: 117-127, 2013.

30. Gao W, Lu C, Chen L and Keohavong P: Overexpression of CRM1: A characteristic feature in a transformed phenotype of lung carcinogenesis and a molecular target for lung cancer adjuvant therapy. $\mathrm{J}$ Thorac Oncol 10: 815-825, 2015.

31. Yang X, Cheng L, Yao L, Ren H, Zhang S, Min X, Chen X, Zhang $\mathrm{J}$ and $\mathrm{Li} \mathrm{M}$ : Involvement of chromosome region maintenance 1 (CRM1) in the formation and progression of esophageal squamous cell carcinoma. Med Oncol 31: 155, 2014.

32. Liu X, Niu M, Xu X, Cai W, Zeng L, Zhou X, Yu R and Xu K: CRM1 is a direct cellular target of the natural anti-cancer agent plumbagin. J Pharmacol Sci 124: 486-493, 2014.

33. Walker CJ, Oaks JJ, Santhanam R, Neviani P, Harb JG, Ferenchak G,Ellis JJ,Landesman Y, Eisfeld AK, Gabrail NY, et al: Preclinical and clinical efficacy of XPO1/CRM1 inhibition by the karyopherin inhibitor KPT-330 in $\mathrm{Ph}+$ leukemias. Blood 122: 3034-3044, 2013. 
34. Theise ND, Curado MP, Franceschi S, et al. Hepatocellular carcinoma. In: classification of tumours of the digestive system, 4th, Bosman FT, Carneiro F, Hruban RH, Theise ND (Eds), IARC, Lyon 2010. p.205.

35. Jain D: Tissue diagnosis of hepatocellular carcinoma. J Clin Exp Hepatol 4 (Suppl 3): S67-S73, 2014.

36. Fleming ID: AJCC/TNM cancer staging, present and future. J Surg Oncol 77: 233-236, 2001

37. Farazi PA and DePinho RA: Hepatocellular carcinoma pathogenesis: From genes to environment. Nat Rev Cancer 6: 674-687, 2006.

38. Stade K, Ford CS, Guthrie C and Weis K: Exportin 1 (Crm1p) is an essential nuclear export factor. Cell 90: 1041-1050, 1997.

39. Ma HX, Shu QH, Pan JJ, Liu D, Xu GL, Li JS, Ma JL, Jia WD, Yv JH and Ge YS: Expression of Kindlin-1 in human hepatocellular carcinoma and its prognostic significance. Tumor Biol 36: 4235-4241, 2015.

40. Yang X, Cheng L, Yao L, Ren H, Zhang S, Min X, Chen X, Zhang $\mathrm{J}$ and $\mathrm{Li} \mathrm{M}$ : Involvement of chromosome region maintenance 1 (CRM1) in the formation and progression of esophageal squamous cell carcinoma. Med Oncol 31: 115, 2014.

41. van der Watt PJ, Maske CP, Hendricks DT, Parker ML, Denny L, Govender D, Birrer MJ and Leanner VD: The Karyopherin proteins, Crm1 and Karyopherin beta1, are overexpressed in cervical cancer and are critical for cancer cell survival and proliferation. Int J Cancer 124: 1829-1840, 2009.

42. Shen A, Wang Y, Zhao Y, Zou L, Sun L and Cheng C: Expression of CRM1 in human gliomas and its significance in p27 expression and clinical prognosis. Neurosurgery 65: 153-159; discussion 159-160, 2009.

43. Chen L, Moore JE, Samathanam C, Shao C, Cobos E, Miller Ms and Gao W: CRM1-dependent p53 nuclear accumulation in lung lesions of a bitransgenic mouse lung tumor model. Oncol Rep 26: 223-228, 2011.

44. Noske A, Weichert W, Niesporek S, Röske A, Buckendahl AC, Koch L, Sehouli J, Dietel M and Denkert C: Expression of the nuclear export protein chromosomal region maintenance/exportin $1 / \mathrm{Xpo1}$ is a prognostic factor in human ovarian cancer. Cancer 112: 1733-1743, 2008.

45. Huang WY, Yue L, Qiu WS, Wang LW, Zhou XH and Sun YL: Prognostic value of CRM1 in pancreas cancer. Clin Invest Med 32: E315, 2009.

46. Lapalombella R, Sun Q, Williams K, Tangeman L, Jha S, Zhong Y, Goettl V, Mahoney E, Berglund C, Gupta S, et al: Selective inhibitors of nuclear export showed that CRM1/XPO1 is a target in chronic lymphocytic leukemia. Blood 120: 4621-4634, 2012.

47. Tai YT, Landesman Y, Acharya C, Calle Y, Zhong MY, Cea M, Tannenbaum D, Cagnetta A, Reagan M, Munshi AA, et al: CRM1 inhibition induces tumor cell cytotoxicity and impairs osteoclastogenesis in multiple myeloma: Molecular mechanisms and therapeutic implications. Leukemia 28: 155-165, 2014.
48. Kojima K, Kornblau SM, Ruvolo V, Dilip A, Duvvuri S, Davis RE, Zhang M, Wang Z, Coombes KR, Zhang N, et al: Prognostic impact and targeting of CRM1 in acute myeloid leukemia. Blood 121: 4166-4174, 2013.

49. Schmidt J, Braggio E, Kortuem KM, Egan JB, Zhu YX, Xin CS, Tiedemann RE, Palmer SE, Garbitt VM, McCauley D, et al: genome-wide studies in multiple myeloma identify XPO1/CRM1 as a critical target validated using the selective nuclear export inhibitor KPT-276. Leukemia 27: 2357-2365, 2013.

50. Azmi AS, Al-Katib A, Aboukameel A, McCauley D, Kauffman M, Shacham S and Aohammad RM: Selective inhibitors of nuclear export for the treatment of non-Hodgkin's lymphomas. Haematologica 98: 1098-1106, 2013.

51. Walker CJ, Oaks JJ, Santhanam R, Neviani P, Harb JG, Ferenchak G, Ellis JJ, Landesman Y, Eisfeld AK, Gabrail NY, et al: Preclinical and clinical efficacy of XPO1/CRM1 inhibition by the karyopherin inhibitor KPT-330 in Ph+ leukemias. Blood 122: 3034-3044, 2013.

52. Forgues M, Marrogi AJ, Spillare EA, Wu CG, Yang Q, Yoshida $\mathrm{M}$ and Wang XW: Interaction of the hepatitis B virus $\mathrm{X}$ protein with the Crm1-dependent nuclear export pathway. J Biol Chem 276: 22797-22803, 2001.

53. Chuanxin Zou, Jiayan Nie, Shaojun Dai, et al: Study of relationships between primary carcinoma of the liver and chronic hepatitis B with positive/negative HBeAg. World Chinese Journal of Digestology 16: 3696-3699, 2008.

54. Biselli M, Conti F, Gramenzi A, Frigerio M, Cucchetti A, Fatti G, D'Angelo M, Dall'Agata M, Giannini EG, et al: A new approach to the use of $\alpha$-fetoprotein as surveillance test for hepatocellular carcinoma in patients with cirrhosis. Br J Cancer 112: 69-76, 2015.

55. Ishizuka M, Kubota K, Kita J, Shimoda M, Kato M, Mori S, Iso $\mathrm{Y}$, Yamagishi $\mathrm{H}$ and Kojima $\mathrm{M}$ : Aspartate aminotransferase-to-platelet ratio index is associated with liver cirrhosis in patients undergoing surgery for hepatocellular carcinoma. J Surg Res 194: 63-68, 2015.

56. Wang FS, Fan JG, Zhang Z, Gao B and Wang HY: The global burden of liver disease: The major impact of China. Hepatology 60: 2099-2108, 2014.

57. Pascale RM, Simile MM, Calvisi DF, Frau M, Muroni MR, Seddaiu MA, Daino L, Muntoni MD, De Miglio MR, Thorgeirsson SS and Feo F: Role of HSP90, CDC37, and CRM1 as modulators of P16(INK4A) activity in rat liver carcinogenesis and human liver cancer. Hepatology 42: 1310-1319, 2005.

58. Ma WJ, Wang HY and Teng LS: Correlation analysis of preoperative serum alpha-fetoprotein (AFP) level and prognosis of hepatocellular carcinoma (HCC) after hepatectomy. World J Surg Oncol 11: 212, 2013. 